\title{
Ewa Kopczyńska*
}

Jagiellonian University

\section{Agata Bachórz**}

University of Gdańsk

\section{FOOD FEARS, FOOD DISTRUST AND FOOD EXCLUSION IN ONE POSTSOCIALIST CULTURE. AND BEYOND}

In societies with industrial food production systems, eating patterns are coming to resemble traditional dining communities less and less. The cultural status of highly processed food reaching the consumer after going through long distribution chains is becoming unclear. The spatial, temporal and symbolic distance between the food system and the consumer's mouth translates into doubts and criticism toward food economies and food itself. Food lacking in stabilized cultural meanings becomes tasteless, disturbing, and harmful.

Uncertainty, distrust and lack of control cause new types of social anxieties. The erstwhile threats associated with seasonal food shortages, i.e. monotonous diets and physically or symbolically polluted food, are being replaced by new ones. These include fear of technological (GMO), epidemiological (BSE, E. coli), cultural and economic threats (endangered local economies and traditions), as well as concerns surrounding the medicalisation and aestheticization of the body (eating disorders, the so-called epidemic of obesity). Social fears and anxieties are expressed at different levels of the social realm: from state public health policies, economic entities, media discourses, and social movements to bottom-up cultural activities and everyday strategies of households. According to many authors (Dunant and Porter 1996; Beck 1992; Bauman 2013; Giddens 1991; Douglas and Wildavsky 1982) social fears are permeating entire cultures on an unprecedented scale. Food fears are part of the picture (Kjærnes, Harvey, and Warde 2007; Blay-Palmer 2008; Jackson 2015; Nestle 2003; Levenstein 2012).

Food fears are closely related to their cultural, political and economic contexts, and therefore we can discern diversified diagnoses of local food systems and different answers

\footnotetext{
* Corresponding author: Ewa Kopczyńska, Uniwersytet Jagielloński, Instytut Socjologii 31-044 Kraków, ul. Grodzka 52; e-mail: ewa.kopczynska@uj.edu.pl.

** Corresponding author: Agata Bachórz, Uniwersytet Gdański, Wydział Nauk Społecznych, ul. Jana Bażyńskiego 4, 80-309 Gdańsk; e-mail: agata.bachorz@ug.edu.pl.
} 
to food threats in various places. The number of sociological and anthropological studies on dietary fears has exploded in the past dozen years. A significant number of these apply to regions of developed capitalist economies, in particular the United States, Great Britain and western European countries. The academic work from these areas focuses on the concerns related to the industrialization of food systems, in particular food production and distribution processes. Developed analyses also examine health and body discourse, in particular in advertising and media, as well as various elements of public health policies regarding food and political economies of the food system.

Similar topics concerning the threats arising from the globalizing food systems are appearing in the systematically growing wave of literature on Eastern European food cultures. This picture is complemented by local trajectories of changes in particular economies. A case study by Zsuzsa Gille devoted to a food scandal over powdered Hungarian paprika, in which a harmful aflotoxin was found in 2004 (Gille 2009), is one example of academic work on food fears with a strong local context. The contamination turned out to come from the channels of Euro-global trade, and EU security regulations did not provide Hungarian consumers with adequate protection. Using the cases of the paprika scandal and the Austrian call for a boycott of Hungarian foie gras in 2008, Gille shows how national and global foodscapes, the flows of goods, food markets, economic and security regulations, consumer moods, etc. are located in the global (here European) system of domination and subordination. On the example of Lithuanian raw milk markets, in turn, Diana Mincyte (2012) describes how consumer practices are shaped in a situation of marginalization and cultural and economic discontinuities. Ethnographic research in Russia by Jennifer Patico provides a description of food framing across the power and neo-colonial perspective: using the axes of local-global, Russian-Western, fresh-'expired', high quality-'Second/Third World' quality (Patico 2003).

A number of other studies (e. g. Caldwell 2004; Caldwell, Dunn and Nestle 2009) on the food systems of Eastern Europe adopt the category of postsocialism as the leading framework for interpreting regional phenomena. Under the conceptual framework of postsocialism, local answers to the shortcomings of food production and distribution systems are described. Those answers include continuous domestic food production, informal food exchange, selfsufficiency strategies, local markets, numerous urban-rural connections, shortened distribution chains, and others. Arising in response to deficiencies of the shortage economy, these local characteristics are currently perceived as a source of remedies for the disadvantages of global capitalism, including inequalities embedded in this system (Dunn 2004; Smith and Jehlička 2007). Thus, they are part of the reflection on historical continuity and, at the same time, dynamics of this part of Europe.

Awareness of the hybridity of cultural orders and interpreting them as embedded in a particular trajectory of social change is one of the characteristics of the "postsocialist framework" (Stenning 2005). The way in which cultural diffusion is carried out under the condition of radical rupture is one of the leitmotifs of postsocialism. In such an anthropologizing narrative, cultural habits become a resource, not a relic or a sign of underdevelopment. Elizabeth Dunn, who studied social relations in a food processing plant in Poland in the 1990s, directly points out the contesting potential of postsocialism. She believes that (the Polish) experience coming from the socialist past may help to create an alternative to the dominant vision of 
Food fears, food distrust and food exclusion in one postsocialist culture. And beyond

interpersonal relations. According to her, this alternative can be applied much more universally than only to Eastern European societies (Dunn 2004)).

A similar interpretation is applied by Smith and Jehlička (2007), who consider Polish and Czech peculiarities related to food distribution and domestic food production to be a strategy of resistance to practices of global capitalism. These authors work to reinterpret postsocialist cultures, as well as problematize the order of imitation and the unilinearity of development. They declare "reframing of the transition experience" and the critical reflection on the prefix "post": Experiences of post-socialism have been far more diverse, and in some cases subversive, than popular accounts of "transition-to" allow (Smith and Jehlička 2007: 407). In this work postsocialism is a hybrid with shades of utopia. It is the experience of postsocialist countries from which Europe could potentially take solutions in the face of the decline of existing economic models. The postsocialist condition is not so much embarrassing otherness, but an alternative that is tactically worth using as a scenario for the future, a toolbox or a reservoir for sustainability cultures. And so, the experience of constant change belongs not only to Eastern Europe, but becomes an immanent attribute of late capitalism as such (Smith and Jehlička 2007). In this approach the modernisation project loses its unified, one-for-all recipe, and becomes bundles of heterogenous and complex relations with various traditions and societies, not only those of Eastern Europe.

Postsocialist foodscape theories are focused on contemporary cultural changes as strongly embedded in a socio-historical context. Therefore they frequently refer to nostalgy (see discussion in: Todorova and Z. Gille 2010), social memory, cultural processes of continuity and rupture, the trauma of food crises, and systemic breakthroughs. The concept of Postsocialism attempts to challenge and reinterpret the axis of the former West-East opposition to capture the changes in the former communist bloc without limiting them to being-in-transition processes. This criticism of modernist, linear visions of social change is also pursued by shifting the emphasis from state and economic analysis towards changes at the micro level, including analysis of local experiences and bottom-up reactions to top-down impacts (Dunn 2004; Červinková 2012). Postsocialism as a perspective thereby offers an opportunity to capture the reorganization of social bonds, trust resources, and civic capital.

A similar approach may be found in the studies of food anxieties and food exclusions presented in this volume. They are linked by historical and geographical location and focus on tensions and anxieties that dynamize contemporary food cultures in Poland. Rooted in anthropological tradition, they raise questions about mechanisms of change and cultural continuity, agency and identity, as well as the creation, maintenance and redefinition of social bonds. They all concern food and food fears performed at the micro-level by everyday practices, cultural habits and consumption rituals inside the private networks. This partly results, from the anthropological approach, the qualitative methods applied by authors and the universally "private" character of food as such. But it also tells us a great deal about food cultures in Eastern Europe, where food in general - and therefore also dietary threats together with the proposed solutions - became a domain of privacy. The novelties of food culture are localized in private life, in family and neighbour networks, as are trust capital, social capital and bottom-up coping strategies within consumption, production and distribution practices. The global problem of distrust, lack of transparency and lack of knowledge regarding the food system takes its specific, local shape. 
In this volume Justyna Straczuk (Risk and Trust. Food-Related Concerns and 'Good' Food Procurement Strategies. From Research into Eating Patterns in Poland) analyses how the postsocialist framing of food distrust is parallel to general distrust toward abstract systems, faceless others, institutions and impersonal rules. This, together with the paradoxical excess of information, cognitive and cultural anomy and gastroanomy, experienced as a general late-modernist condition is answered by turning to bottom-up remedies: close ties, private resources, and family and neighbour networks. Straczuk refers to classic sociological theories of trust and applies them in the context of radical cultural changes that Eastern Europe is the arena for. It is noteworthy, however, that the historical/political shift of the early 1990s is definitely not the only, nor the main point, of reference here. Straczuk is, in her interpretation, close to Smith and Jehlička, and considers scepticism toward formal institutional structures as a cultural characteristic and resistance strategy.

Local answers to global threats of food systems also are illustrated in Social contexts of food exclusion by Joanna Krukowska and Dorota Rancew-Sikora. The ongoing individualisation of food patterns reflecting the contemporary cultural disintegration generates profound fears of broken social ties and disappearing food communities. Krukowska and Rancew-Sikora differentiate today's food exclusions from traditional taboos: the latter consolidate, regulate and strengthen the boundaries of social life, whereas the former lead to further individualisation, isolation and social exclusion. The analyses of cases of food exclusion, following both serious medical conditions and individual value and lifestyle choices, unveils the processes of bottom-up renegotiations of everyday food practices within close circles of friends and family. Food excluders not only adapt their diets to participate in social events, but they change their food environment: they become food experts, transform their communities, proceed with their innovation, and loosen the limitations of "traditional" mainstream food culture.

Similar processes of avoiding of social exclusion under the conditions of highly individualized diets are described by Anna Chowaniec (Fat-free, high in calories. Management of the diet in case of rare metabolic disorder). Extreme medical restrictions imposed on food habits of children suffering from the rare metabolic disorder LCHADD require extraordinary control and caution in eating practises. Severe social threats are added to the serious health threats parents have to face. An enormous amount of work is performed not only to protect the children's physical existence, but also to ensure at least basic sociability: participation in family meals, school lunches, birthday parties, etc. Again, private networks, friends-andfamily social capital, informal information sources, know-how and other cultural resources are employed to rise to challenges both physical and social.

LCHAAD patients' positions within the food system are unique and strongly determined. We can thus observe some peculiar framings and practices of material resources: e.g. how the widening market of fat-free products opens up new options not only to adhere to a strict fat-free diet, but also to maintain social relations, build an inclusive community and fulfil the elementary psychological and social needs of patients and their families. Both of the articles about food excluders expose relationality and social and economic embeddedness of food fears. Both are relevant for studying East European food cultures in their dynamics, changing economic systems, and consumption regimes, and both help us understand how particular social actors use various kinds of resources to cope with challenges and threats. 
Food fears, food distrust and food exclusion in one postsocialist culture. And beyond

They are neither unique nor limited to the postsocialist condition, although they are shaped and performed in a given socio-economic environment.

The specific traditional traits of the Eastern European environment are, however, translated and re-framed, becoming "hidden resources" (Agata Bachórz, Hidden resources? Households' strategies for maintaining control over food: between continuity and discontinuity). Domestic cooking, being the unquestionable foundation of Polish food culture, is provided today with a new legitimacy: health, slow-food values, cultural and political identification, supporting regional traditions and economies. Then, despite the simultaneous demand for convenient foods and functional foods, the increasing supply of processed food, and disappearing know-hows, domestic cooking is still performed not as a hobby or occasional practice, but as an ongoing everyday food pattern. Agata Bachórz describes in detail how the past is used as a resource in constructing new - but at the same time highly traditional - food habits.

The reframing and constant redefining of food practices is not exclusively a consequence of the particular historical trajectory of Eastern Europe. In fact, all food cultures are formed and modified by an ongoing discourse of different actors, consumers included. Ewa Kopczyńska (How Food Fears Frame Criticisms of the Food System. A Case Study of Customers of Farmers 'Markets) interprets the shopping strategies of customers of farmers' markets in the light of the theoretical concept of food fears. She argues that identifying and choosing the right - i.e. natural, fresh, and trusted - products is embedded in definitions and preferences for the right social and material order (as in the case of LCHAAD patients). These orders are historically unique and localised, but food decisions are never only about the product itself; sometimes they are not about product at all - when disappointment over the "beautiful vegetables" in the supermarket becomes a synecdoche for joining the global, industrialized food system. Following this wide understanding of food realty, one must notice that there are lifestyles, social roles, economies and institutions consumers enter with their food practices - not just material objects on the supermarket shelf, with their "here and now" attributes.

The papers in this volume illustrate how using resources from the past can be a response to the threats of what is seen as external influence. Food uncertainty often concerns the global economy, the capitalist system, the transforming production and distribution system, new technologies, selling and marketing methods, etc. Therefore, the lack of trust is directed not only toward cultural dynamics of late modernity, but also toward domination of the Western centre of the food system. The resistance embedded in food fears has not only temporal, but also spatial and political dimensions. Openly expressed food fears as well as informal, bottom-up alternative-seeking in certain contexts can be then interpreted as indirect criticism of the transformations the Polish economy and culture have been undergoing.

Those processes of framing, experimenting, coping with, resisting, and more are neither smooth nor unilinear. There are conflicts, discrepancies, dead-end streets, abandoned innovations and failed experiments. This non-linearity, complexity and openness of the food reality is vividly sketched in Fatalité de la maison. Food trauma in post-transition Polish pop culture by Agata Michalak. She follows the steps of Polish artists - a writer, a musician, a director - in their food-related representations. The picture we are provided with is far from clear, but nonetheless intriguing and open to interpretation. In art, food reveals its nature as a nexus of bodily, psychical, material and societal reality. The parallels between 
eating disorders and cultural disorders can be noticed in the absurdity of women's dieting, as the usual materiality of consumption is transgressed when an utterly vulnerable teenager girl (the heroine of Dorota Maslowska's novel White and Red) vomits up stones, and ideological traps are exposed by a witch making an informed decision to exclude humans from her diet (Maslowska's play How Have I Become a Witch). The interpretation we are provided with is definitely based in the postsocialist condition. This condition and these threats are not, however, unique to Eastern Europe. The state of transition is not limited to postsocialist countries in their post-revolution decades.

Using various narratives on eating anxieties, this volume raises questions on postsocialism as an analytical device. This interpretative frame was founded as a means of criticism of unilinear concepts of transition and as an alternative tool for grasping peculiarities of the EEC after communism collapsed. But this frame must be challenged in order to avoid simplifications, to halt further inequalities in knowledge production and to problematize a simplified dual picture of Europe (Červinková 2012). Using the postsocialist framework should not prevent us from identifying and analysing the diversities and various dimensions of East European cultures. Neither should the concept of Postsocialism blind us to more general aspects of cultural processes, nor should it result in the proliferation of unique case studies restraining from more generalized conclusions. Then we apply the postsocialism frame not to sum up but to open up discussions of modernization, to trace complex relations of modernization and tradition, to identify the meanings it has for different people in different places, and to problematize individual agency within macro-processes.

\section{REFERENCES}

Bauman, Zygmunt. 2013. Liquid fear, Hoboken, New Jersey: John Wiley \& Sons.

Beck, Ulrich. 1992. Risk society: Towards a new modernity, Thousand Oaks, California: Sage Publications.

Blay-Palmer, Alison. 2008. Food fears: From industrial to sustainable food systems, Farnham: Ashgate Publishing, Ltd.

Caldwell, Melissa L. 2004. Not by bread alone: social support in the new Russia, Oakland, California: University of California Press.

Caldwell, Melissa L., Elizabeth C. Dunn, and Marion Nestle (ed.). 2009. Food and everyday life in the postsocialist world, Bloomington, Indiana: Indiana University Press.

Červinková, Hana. 2012. Postcolonialism, postsocialism, and the anthropology of east-central Europe, "Journal of Postcolonial Writing", 48, 2: 155-163.

Douglas, Mary and Aaron Wildavsky. 1982. Risk and culture: An essay on the selection of technical and environmental dangers, Oakland, California: University of California Press.

Dunant, Sarah and Roy Porter. 1996. The age of anxiety, London: Virago Press.

Dunn, Elizabeth. 2004. Privatizing Poland: Baby Food, Big Business, and the Remaking of Labor, Ithaca, New York: Cornell University Press.

Giddens, Anthony. 1991. Modernity and self-identity: Self and society in the late modern age, Redwood City, California: Stanford University Press. 
Gille, Zsuzsa. 2009. The Tale of the Toxic Paprika: The Hungarian Taste of Euro-Globalization, in: Melissa L. Caldwell, Elizabeth C. Dunn and Marion Nestle (ed.), Food and everyday life in the postsocialist world, Bloomington, Indiana: Indiana University Press, pp. 97-128.

Jackson, Peter. 2015. Anxious appetites: Food and consumer culture, London: Bloomsbury Publishing.

Kjærnes, Unni, Mark Harvey and Alan Warde. 2007. Trust in food: A comparative and institutional analysis, New York City: Springer.

Levenstein, Harvey. 2012. Fear of Food: A history of why we worry about what we eat, Chicago: University of Chicago Press.

Mincyte, Diana. 2012. How milk does the world good: vernacular sustainability and alternative food systems in post-socialist Europe, "Agriculture and Human Values", 29, 1: 41-52.

Nestle, Marion. 2003. Safe food: Bacteria, biotechnology, and bioterrorism, Oakland, California: University of California Press.

Patico, Jennifer. 2009. Spinning the market. The moral alchemy of everyday talk in postsocialist Russia, "Critique of Anthropology", 29, 2: 205-224.

Smith, Joe and Petr Jehlička. 2007. Stories about food, politics and change in Poland and the Czech Republic, "Transactions of the Institute of British Geographers. New Series", 32, 3: 395-410.

Stenning, Alison. 2007. Post-socialism and changing geographies of the everyday in Poland, "Transactions of the Institute of British Geographers", 30: 113-127.

Todorova, Maria N. and Zsuzsa Gille. 2010. Post-communist Nostalgia, New York: Berghahn Books. 